Ege Tıp Dergisi / Ege Journal of Medicine 2020; 59 (2): 109-112

\title{
Miyelofibrozisli olgularda allojenik kök hücre nakil sonuçlarımız: tek merkezli, retrospektif bir analiz
}

\section{Allogeneic stem cell transplantation in patients with myelofibrosis: single center, retrospective study}

\begin{tabular}{|c|c|c|}
\hline & Nurcan Öz & $n^{2}$ \\
\hline & 4 & \\
\hline aya $^{1}(\mathbb{D}$ & Emine Tülay Özcelik ${ }^{1}$ (D) & $\mathrm{ML}$ \\
\hline
\end{tabular}

${ }^{1}$ Demiroğlu Bilim Üniversitesi Tıp Fakültesi, Hematoloji Bilim Dalı, İstanbul, Türkiye

${ }^{2}$ Şişli Florence Nigthingale Hastanesi, Hematopoetik Kök Hücre Nakil Ünitesi, İstanbul, Türkiye

3 Bakırköy Dr. Sadi Konuk Eğitim ve Araştırma Hastanesi, Hematoloji Bölümü, İstanbul, Türkiye

${ }^{4}$ Yeni Yüzyıl Üniversitesi, Gazi Osman Paşa Hastanesi, Kemik Illiği Nakil Merkezi, İstanbul, Türkiye

Öz

Amaç: Primer miyelofibrozis (PMF), kronik miyeloproliferasyon, atipik megakaryositik hiperplazi ve kemik iliği fibrozisi ile karakterize klonal bir kök hücre hastalığıdır. Bu hastalarda günümüzde halen gösterilebilmiş tek şifa sağlayıcı tedavi seçeneği olan allojenik kök hücre nakli, ülkemiz Sağlık Bakanlığı endikasyon listesine göre DIPPS skoru orta-2 veya yüksek riskli birincil veya ikincil miyelofibrozisli hastalara önerilmektedir. Çalışmamızda miyelofibrozisli hastalarımızın allojenik nakil sonrası takip verilerini paylaşmayı amaçladık.

Gereç ve Yöntem: Geriye dönük ve kesitsel bu değerlendirmeye Şişli Florence Nightingale Hastanesi Hematopoetik Kök Hücre Nakil Merkezinde 2011-2016 yılları arasında allojenik nakil yapılan ve takipte olan toplam dokuz miyelofibrozis tanılı olgu dahil edildi. Olguların tüm demografik özellikleri yanı sıra, DIPPS-plus skorları, engrafman süreleri, graft versus host hastalığı (GVHH) görülme sıklıkları gibi parametreler ve sağ kalım verileri kaydedildi.

Bulgular: Olguların ortalama yaşları 49,7 (34-63) yıl idi. Tanı ile transplant arası geçen süre ortalama 30,2 ay $(1,7-65,2)$ idi. Tam uyumlu kardeş nakil altı olguda ve akraba dışı nakil üç olguda yapıldı. Tam uyumlu kardeş nakilde, nötrofil engraftman süresinin akraba dışı nakile göre anlamlı kısa iken, trombosit engraftman sürelerinin ise tam uyumlu kardeş nakilde kısa olma eğilimi ile birlikte istatistiksel anlamlı farklılık göstermediği izlenmiştir. Toplam dokuz hastanın takibinde üç olguda $(\% 33,4)$ akut, altı olguda $(\% 66,6)$ kronik GVHH geliştiği izlenmiştir. Kümülatif sağ kalım beş yıllık \%70'dir.

Sonuç: Merkezimizde miyelofibrozisli olguların değerlendirmelerinde, özellikle toplam sağ kalım oranı literatürdeki birçok seriye göre yüksek görünmektedir. Hasta sayısının az oluşu önemli bir sınırlama olmakla birlikte hem yaş hem de verici çeşitliliği mevcuttur. Ayrıca yüksek GVHH oranlarına karşın sağ kalımın yüksek kalmasının, hasta takibinin ve komplikasyonların iyi yönetiminin önemini vurguladığını düşünüyoruz.

Anahtar Sözcükler: Allojenik kök hücre nakli, miyelofibrozis.

\section{Abstract}

Aim: Primary myelofibrosis (PMF) is a clonal stem cell disease characterized by chronic myeloproliferation, atypical megakaryocytic hyperplasia and bone marrow fibrosis. Allogeneic stem cell transplantation, which is the only curative treatment option, is recommended for patients diagnosed with DIPSS moderate-2 or high-risk primary or secondary myelofibrosis according to the Turkish Ministry of Health indication list. In this study, we aimed to share the follow-up data after allogeneic transplantation of our patients with myelofibrosis.

\footnotetext{
Sorumlu yazar: Deniz Gören Şahin

Demiroğlu Bilim Üniversitesi Tıp Fakültesi, Hematoloji Bilim

Dalı, İstanbul, Türkiye

E-posta: drdenizgoren@gmail.com

Başvuru tarihi: 17.07.2019 Kabul tarihi: 17.12.2019
} 
Materials and Methods: This retrospective and cross-sectional evaluation included 9 cases of myelofibrosis that underwent allogeneic transplantation between 2011 and 2016 at Şişli Florence Nightingale Hospital Hematopoietic Stem Cell Transplantation Center. All demographic characteristics and parameters such as DIPPS-plus scores, engraftment times, frequency of graft versus host disease, and survival data were recorded.

Results: The mean age of the patients was 49.7 (34-63) years. The mean time from diagnosis to transplantation was 30.2 months (1.7-65.2). Matched sibling donor was used in 6 cases and matched unrelated donor in 3 cases. It was observed that neutrophil engraftment time was significantly shorter than matched unrelated donor transplantation when compare to matched related donor transplantation, whereas platelet engraftment times did not show a statistically significance. Acute GVHD developed in 3 patients (33.4\%) and chronic GVHD in 6 patients (66.6\%). Cumulative survival is $70 \%$ for 5 years.

Discussion: In our center, the overall survival rate in patients with myelofibrosis after allogeneic transplantation seems to be high compared to many series in the literature. Although the small number of patients is an important limitation, there is both age and donor variety. On the other hand, the fact that GVHD was seen at a higher frequency compared to the literature and the survival rate remains high, which emphasizes the importance of post-transplant patient follow-up and good management of the complications.

Keywords: Allogeneic stem cell transplantation, myelofibrosis.

\section{Giriş}

Primer miyelofibrozis, Dünya Sağlık Örgütü'nün sınıflamasına göre, esansiyel trombositoz ve polistemia vera ile birlikte miyeloproliferatif neoplazmlar (MPN) başlığı altında sınıflanmakta olan, miyeloid hücrelerin klonal proliferasyonu neticesinde ortaya çıkan ve JAK2, CALR ve MPL gibi rekürren mutasyonlarla karakterize, nadir bir hastalıktır (1). Klinikte, konstitüsyonel semptomlar, anemi, hepatosplenomegali gibi bulgular ve periferik kan yaymasında lökoeritroblastik tablonun görülmesi tipiktir. Sağ kalım sürelerinin ortalama altı yıl olduğu bilinen primer miyelofibrozisli olgularda, yaş azaldıkça bu süre özellikle 60 yaş altındaki olgularda ortalama 15 yıla kadar çıkabilmektedir (2). Son yıllarda, primer miyelofibrozis için risk grupları oluşturarak tedaviyi yönetimini şekillendirme amacıyla çeşitli prognostik modeller tanımlanmıştır. Bunlardan ilki 2009 yılında tanımlanan IPSS (international prognostic scoring system) olup, bunu dinamik formu DIPSS ve ardından genişletilmiş formu olan DIPSS-plus izlemiştir (3-5). Bununla birlikte günümüzde Jak2 inhibitörleri dahil çeşitli medikal tedavi seçeneklerinde gelişmeler olsa da, halen tek tedavi edici seçenek allojenik kök hücre naklidir (6). Ülkemizde de Sağlık Bakanlığı endikasyon listesine göre de klinik pratikte en sık kullanılan skorlama sistemlerinden biri olan DIPPS'e göre risk skoru orta-2 veya yüksek riskli primer veya ikincil miyelofibrozis tanılı hastalara, performans durumları ve yaş göz önüne alınarak allojenik kök hücre nakli yapılması önerilmektedir. Allojenik kök hücre nakli tedavi edici bir yaklaşım olmakla birlikte, nakil ile ilişkili mortalite oranlarının da literatürde \%20-30 arasında olduğu bilinmektedir. $\mathrm{Bu}$ çalışmadaki amacımız, allojenik kök hücre nakli yaptığımız primer miyelofibrozisli olgularımıza ait nakil sonuçlarımızın

paylaşılmasıdır.

\section{Gereç ve Yöntem}

$\mathrm{Bu}$ çalışmaya Şişli Florence Nightingale Hastanesi Hematopoetik Kök Hücre Nakil Merkezinde 2011-2016 yılları arasında allojenik kök hücre nakli yapılan ve takipte olan toplam dokuz primer miyelofibrozis tanılı olgu dahil edilmiştir. Çalışma retrospektif ve kesitsel niteliktedir. Çalışma için 2019 yılında Demiroğlu Bilim Üniversitesi Tıp Fakültesi girişimsel olmayan araştırmalar etik kurulu tarafından onay alınmıştır. Çalışmaya dahil edilen tüm olgular 18 yaş üzeri olup, 2016 yılı Dünya Sağlık Örgütü kriterlerine göre primer miyelofibrozis tanısı almış ve DIPSS skoru ile orta-2 veya yüksek riskli hastalığın varlığının gösterildiği olgulardır. Tüm olguların yaş, cinsiyet, eşlik eden hastalık (komorbidite) varlığı gibi demografik özellikleri geriye dönük olarak taranmıştır. Bunun yanı sıra, DIPPS skorları, takip ve nötrofil/trombosit engraftman süreleri (nötrofil engraftmanı; absolü

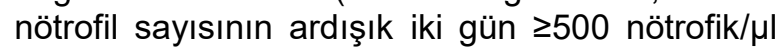
ve trombosit engraftmanı ise trombosit sayısının trombosit transfüzyonu yapılmaksızın ardışık 2 gün süreyle $\geq 20,000$ trombosit/ $\mu$ l olması olarak tanımlanmıştır), graft versus host hastalığı $(\mathrm{GVHH})$ görülme sıklıkları gibi parametreler ile sağ kalım verileri kaydedilmiştir. 
Çalışmanın istatistiksel analizleri IBM SPSS versiyon 20.0 kullanılarak yapılmıştır. Normal dağılımın analizinde Shapiro-Wilk testi, değişkenlerin karşılaştırmalarında T-testi ve sağ kalım verileri için Kaplan-Meier analizleri kullanılmıştır. $P$ değeri $<0,05$ istatistiksel olarak anlamlı kabul edilmiştir.

\section{Bulgular}

Çalışmaya alınan olguların ortalama yaşları 49,7 (34-63) yıl idi. Erkek/kadın oranı $6 / 3$ olarak izlendi. Toplam dokuz olgunun altısında DIPSSplus skoru 4'ün üzeri olup yüksek risk grubuna dahil edilirken, diğer üç hasta orta-2 risk grubuna dahil edilmişti. Hiçbir hastanın öyküsünde transplant öncesi dönemde splenektomi veya splenik radyoterapi uygulaması söz konusu değildi. Yine bir hasta dışında nakil öncesi dönemde JAK-2 inhibitörü kullanan hasta yoktu. Hastaların genetik özellikleri incelendiğinde beş hastanın JAK-2 pozitif, iki hastanın ise MPL pozitif olduğu görüldü. Ayrıca hastalardan birinde konvansiyonel kromozom analizinde kompleks karyotip varlığı gösterilmişti. İki hasta ise klasik genetik mutasyonların hiçbirini taşımıyordu.

Hastalarda tanı ile transplant arası geçen süre ortalama 30,2 ay $(1,7-65,2)$ idi. Donör tipi açısından tam uyumlu kardeşten nakil altı olguda ve akraba dışı nakil ise üç olguda gerçekleştirilmişti. Tüm olgularda kök hücre kaynağı olarak periferik kan kök hücre kullanılmıştı. Hazırlık rejimi olarak altı olguda $(\% 66,6)$ miyeloablatif ve üç olguda $(\% 33,4)$ ise azaltılmış yoğunluklu hazırlık rejimi tercih edilmişti. Nakil sonrası döneme bakıldığında tam uyumlu kardeşten yapılan nakilde, nötrofil engraftman (absolü nötrofil sayısı $>500 \times 10^{3} / \mu \mathrm{L}$ ) süresinin akraba dışı nakle göre anlamlı derecede kısa olduğu (sırasıyla 16 gün ve 23,6 gün, $\quad p=0,042$ ), trombosit engraftman (trombosit>20.000 $\times 10^{3} / \mu \mathrm{L}$ ) sürelerinin ise tam uyumlu kardeş nakilde kısa olma eğilimi ile birlikte istatistiksel anlamlı farklılık göstermediği (sırasıyla 16,6 gün ve 20,3 gün, $p=0,09$ ) izlenmiştir.

Toplam dokuz hastanın takibinde üç olguda $(\% 33,4)$ akut, altı olguda $(\% 66,6)$ ise kronik GVHH geliştiği izlenmiştir. Olguların genel sağ kalım verisi Şekil-1'de gösterilmiştir. İki olgu sepsis nedenli kaybedilmiş olup, yedi olgu halen remisyonda izlenmektedir. Yaşayan hastalar için ortalama takip süresi 66,5 ay olarak belirlenmiştir. Hastaların beş yıllık kümülatif sağ kalım oranı $\% 70$ olarak bulunmuştur.

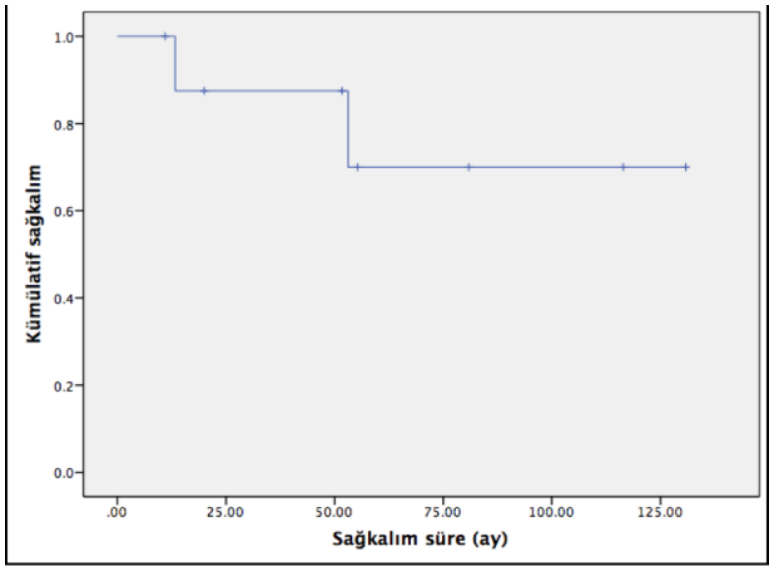

Şekil-1. Allojenik kök hücre nakli yapılan miyelofibrozis olgularımızın sağ kalım eğrisi.

\section{Tartışma}

$\mathrm{Bu}$ çalışmada, merkezimizde miyelofibrozisli olguların yapılan allojenik nakil sonrası geriye dönük değerlendirme sonuçları paylaşılmıştır. İleri yaş ve düşük performans durumuna sahip olguların allojenik nakil sonrası relaps dışı mortalite oranlarının yüksek olduğu bilinmektedir. $\mathrm{Bu}$ nedenle performans durumu iyi ve 65 yaş ve altındaki hastalara yüksek riskli hastalık varlığında allojenik nakil önerilmektedir (7). Bizim olgularımızın yaş ortalamasının ve hastaların performans durumlarının allojenik nakil için genel literatürde kabul edilebilir ve önerilen nitelikte olduğu izlenmiştir. Aynı şekilde risk skorlamasında DIPSS'e göre tüm hastaların orta2 ve yüksek risk grubu dâhilinde oldukları izlenmiştir.

Donör tipi, nakil sonuçlarını etkileyen önemli bir faktör olup, tam doku grubu uyumlu olmayan vericiden yapılan nakil ile relaps dışı mortalite oranlarının daha yüksek olduğu bilinmektedir (8). Hastalarımızın tümüne HLA tam uyumlu kardeş veya 10/10 uyumlu akraba dışı vericilerden nakil yapıldığı izlenmiştir. Hasta sayısı itibariyle bu iki grup arasında bir istatistiksel karşılaştırma yapmak mümkün olmamıştır. Bununla birlikte literatüre bakıldığında prospektif bir EBMT çalışmasında (9), relaps dışı mortalitenin kümülatif insidansının HLA uyumlu kardeş verici ve 10/10 uyumlu akraba dışı verici arasında istatistiksel anlamlı farklılık göstermediği (sırasıyla \%10 ve \%13) izlenmiş olup, daha sonra bu bulguyu destekleyen retrospektif çalışmalar da yayınlanmıştır $(10,11)$.

Çalışmamızda tam uyumlu kardeş vericiden yapılan nakil sonrası nötrofil ve trombosit engraftman sürelerinin daha kısa olduğu 
gözlenmiştir. Schmol ve ark. (12) tarafından yapılan bir retrospektif analizde de engfratman süreleri değerlendirilmiştir. Miyelofibrozis tanılı 54 hastanın allojenik nakil sonrası değerlendirmelerinde nötrofil engraftmanının ortalama 22 günde, trombosit engraftmanının ise ortalama 25 günde gerçekleştiği ve özellikle trombosit engraftman sürelerinin, tam uyumlu kardeş vericiden yapılan nakillerde, akraba dışı nakillere göre anlamlı ölçüde kısa olduğu izlenmiştir.

Toplam sağ kalım verileri değerlendirildiğinde, bizim verilerimiz literatürdeki birçok seride mevcut üç yılda yaklaşık \%44'lük sağ kalım değerlerine göre yüksek görünmektedir. Bununla birlikte yakın zamanda Robin ve ark. (13) tarafından Avrupa Kemik İliği Transplantasyon Grubu (EBMT)'nin uzun dönem verileri paylaşılmıştır. Bu yayına 1995-2014 yılları arasında toplam 1055 myelofibrozis tanılı hasta dahil edilmiş ve ilk iki yılı remisyonda tamamlayan olguların 10 yıllık sağ kalım oranlarının \%74 olduğu izlenmiştir.

\section{Sonuç}

Hasta sayısının az oluşu çalışmamızdaki önemli bir sınırlamadır ve sağ kalım verilerinin karşılaştırılmasını zorlaştırmaktadır. Bununla olmakla birlikte hem yaş hem de verici çeşitliliği mevcuttur. Diğer yandan literatüre göre daha yüksek sıklıkta GVHH görülmüş olması ve buna rağmen sağ kalımın yüksek kalması, transplantasyon sonrası dönemdeki hasta takibinin ve ortaya çıkan komplikasyonların iyi yönetiminin önemini vurgulamaktadır.

Çıkar çatışması: Yazarlar çıkar çatışması beyan etmemişlerdir.

\section{Kaynaklar}

1. Tefferi A. Primary myelofibrosis: 2019 update on diagnosis, risk-stratification and management. Am J Hematol. 2018; 93: 1551-60.

2. Tefferi A, Guglielmelli $P$, Larson DR, Finke C, Wassie EA, Pieri L, et al. Long-term survival and blast transformation in molecularly annotated essential thrombocythemia, polycythemia vera, and myelofibrosis. Blood. 2014; 124: 2507-13; quiz 615.

3. Cervantes F, Dupriez B, Pereira A, Passamonti F, Reilly JT, Morra E, et al. New prognostic scoring system for primary myelofibrosis based on a study of the International Working Group for Myelofibrosis Research and Treatment. Blood. 2009; 113: 2895-901.

4. Passamonti F, Cervantes F, Vannucchi AM, Morra E, Rumi E, Cazzola M, et al. Dynamic International Prognostic Scoring System (DIPSS) predicts progression to acute myeloid leukemia in primary myelofibrosis. Blood. 2010; 116: 2857-8.

5. Gangat N, Caramazza D, Vaidya R, George G, Begna K, Schwager S, et al. DIPSS plus: a refined Dynamic International Prognostic Scoring System for primary myelofibrosis that incorporates prognostic information from karyotype, platelet count, and transfusion status. J Clin Oncol. 2011; 29: 392-7.

6. Lavi N, Rowe JM, Zuckerman T. Allogeneic stem-cell transplantation for myelofibrosis. Curr Opin Hematol. 2017; $24: 475-80$.

7. Kroger N, Giorgino T, Scott BL, Ditschkowski M, Alchalby H, Cervantes F, et al. Impact of allogeneic stem cell transplantation on survival of patients less than 65 years of age with primary myelofibrosis. Blood. $2015 ; 125$ : 3347-50; quiz 64

8. Kroger NM, Deeg JH, Olavarria E, Niederwieser D, Bacigalupo A, Barbui T, et al. Indication and management of allogeneic stem cell transplantation in primary myelofibrosis: a consensus process by an EBMT/ELN international working group. Leukemia. 2015; 29: 2126-33.

9. Kroger N, Holler E, Kobbe G, Bornhauser M, Schwerdtfeger R, Baurmann H, et al. Allogeneic stem cell transplantation after reduced-intensity conditioning in patients with myelofibrosis: a prospective, multicenter study of the Chronic Leukemia Working Party of the European Group for Blood and Marrow Transplantation. Blood. 2009; 114: 5264-70.

10. Devlin R, Gupta V. Myelofibrosis: to transplant or not to transplant? Hematology Am Soc Hematol Educ Program. 2016; 2016: 543-51.

11. Shanavas M, Popat U, Michaelis LC, Fauble V, McLornan D, Klisovic R, et al. Outcomes of Allogeneic Hematopoietic Cell Transplantation in Patients with Myelofibrosis with Prior Exposure to Janus Kinase 1/2 Inhibitors. Biol Blood Marrow Transplant. 2016; 22: 432-40.

12. Schmohl JU, Groh C, Faul C, Vogel W, Mohle R, Wirths S, et al. Allogeneic hematopoietic cell transplantation in patients with myelofibrosis: A single center experience. Ann Hematol. 2016; 95: 973-83.

13. Robin M, de Wreede LC, Wolschke C, Schetelig J, Eikema DJ, Van Lint MT, et al. Long-term outcome after allogeneic hematopoietic cell transplantation for myelofibrosis. Haematologica 2019 Sep;104(9):1782-8. doi: 10.3324/haematol.2018.205211 